\title{
Analisis Pendapatan Usahatani Dusung Di Desa Hutumuri Kota Ambon
}

\author{
Lanny Wattimena
}

Universitas Viktori Sorong

lannywattimena@gmail.com

\begin{abstract}
Abstrak
Penelitian ini dilakukan di Desa Hutumuri Kota Ambon. Penentuan daerah penelitian dilakukan secara purposive, sampel diambil sebanyak 45 petani.

Tujuan penelitian adalah untuk mengetahui besarnya biaya dan pendapatan yang diperoleh petani dari usahatani dusung, mengetahui tingkat kemiskinan petani yang mengusahakan usahatani dusung dan mengetahui faktor-faktor yang mempengaruhi usahatani dusung. Selanjutnya data dianalisis dengan menggunakan analisis pendapatan usahatani, tingkat kemiskinan menurut Sayogyo, berdasarkan konsep Bank Dunia dan menurut Upah Minimum Provinsi Maluku serta analisis regresi.

Hasil penelitian menunjukkan bahwa usahatani dusung di Desa Hutumuri Kota Ambon masih produktif sebagai sumber pendapatan karena memberikan kontribusi yang tinggi bagi petani dibandingkan dengan UMP yang ditetapkan Pemerintah Provinsi Maluku. Faktor-faktor yang berpengaruh terhadap pendapatan petani dari usahatani dusung adalah luas lahan, umur, penyusutan peralatan, jumlah tanggungan keluarga, lamanya berusahatani dusung, pendidikan dan dummy. Pendapatan usahatani dusung berada di atas tingkat kemiskinan disebabkan pendapatan petani dari usahatani dusung per tahun disetarakan dengan kilogram beras di atas $480 \mathrm{~kg}$ berdasarkan kriteria Sayogyo, bahkan di atas tingkat kemiskinan menurut Bank Dunia dan di atas Upah Minimum Provinsi Maluku. Ini menunjukkan bahwa petani dusung sejahtera karena pendapatan usahatani dusung masih memberikan peranan penting dalam peningkatan kesejahteraan rumah tangga petani di daerah penelitian.
\end{abstract}

Kata Kunci : Dusung, Pendapatan, Tingkat Kemiskinan.

\section{PENDAHULUAN}

Pengembangan diarahkan pada pertumbuhan skala besar paralel dengan skala kecil yang besar paralel dengan skala kecil yang memerlukan rangkaian penanganan yang efisien dan ekonomi. Dalam masa yang akan datang pengembangan komoditas disesuaikan dengan daya saing dukungan lahan, potensi pasar yang baik, juga mampu meningkatkan aktivitas ekonomi pedesaan (Soerodjo, 1993).

Meningkatnya pembangunan pertanian akan meningkatkan kebutuhan lahan sehingga terjadi keterbatasan lahan pertanian. Pengusahaan lahan yang terbatas tersebut menyebabkan produksi pertanian turun sehingga pendapatan rendah dan tak layak bagi kesejahteraan masyarakat. Salah satu usaha mengatasi keterbatasan lahan adalah pemilihan alternatif lahan berupa lahan kering yaitu lahan hutan. Akan tetapi pola tanam yang diterapkan masih belum berwawasan lingkungan. Keseimbangan ekologi jangka panjang terganggu karena kondisi lahan yang tak subur lagi. Hal tersebut terjadi karena 
pemanfaatan lahan yang masih cenderung bersifat eksploitasi sumberdaya, sehingga berakibat pada kerusakan lingkungan. Menurut Soedardjo (1993), kerusakan lahan terjadi akibat penggunaan lahan yang melebihi kapasitas penggunaan lahan. Usaha pelestarian sumberdaya alam belum banyak diarahkan pada optimalisasi pola usahatani melalui pemilihan komoditas ekonomis dalam usaha intensifikasi dan diversifikasi pertanian. Penerapan sistem agroforestry adalah untuk menjawab permasalahan diatas.

Dewasa ini konsep

mengkombinasikan pertanian murni dengan kehutanan mulai dikembangkan. Konsep agroforestry ini muncul sebagai suatu sistem untuk mengkombinasikan kebijakan pertanian yaitu produktifitas tinggi dari tanaman pangan dan kehutanan yaitu mengurangi erosi dan mempertahankan kesuburan tanah (Oszaer, 1996). Sistem agroforestry dengan beragam jenis dan fungsi tanamannya menghasilkan berbagai produk pertanian dan kehutanan yang sangat diperlukan petani dalam memenuhi kebutuhan hidup pokok sehari-hari, namun biasanya tidak dalam skala besar (cukup untuk keperluan keluarga dan sedikit lebihnya untuk dijual). Produk dari agroforestry antara lain : kebutuhan pangan, papan, pakan, industri dan lain-lain (Muniarti dan Siregar, 1996).

Sistem agroforestry yang diterapkan harus mengarah pada sistem pertanian konservasi, yaitu sistem pertanian yang mengintegrasikan teknik konservasi tanah dan air kedalam sistem pertanian yang telah ada dengan tujuan untuk meningkatkan pendapatan petani, meningkatkan kesejahteraan petani dan sekaligus menekan erosi, sehingga sistem pertanian tersebut dapat berlanjut secara terus-menerus. Jadi tujuan utama bukanlah menerapkan tindakan konservasi tanah saja, tetapi untuk mempertahankan pertanian yang lestari (M. Badrun, 2000).

Sistem agroforestry sudah lama dikenal dan dipraktekkan oleh para petani di Indonesia, khususnya di Maluku yang dikenal dengan sistem dusung. Dusung merupakan budaya turun-temurun dari masyarakat Maluku, khususnya di kota Ambon yang pola pembentukannya berlangsung melalui beberapa tahapan, yaitu pola ewang kebun - aong - dusung yang dalam bahasa sehari-hari masyarakat setempat dikenal dengan pola ewang - kabong aong - dusong (Ayawaila, 1996).

Pengusahaan dusung di Maluku, khususnya kota Ambon dilaksanakan menurut pola farm forestry yang merupakan perpaduan antara kegiatan pertanian dan kehutanan di daerah sekitar tempat tinggal masyarakat. Dengan demikian, dusung merupakan lahan garapan sebagai sumber mata pencaharian bagi masyarakat (petani), dan juga penggunaan berbagai jenis tanaman umur panjang seperti cengkeh, pala, durian, langsat dan tanaman semusim seperti umbi-umbian, merupakan komoditi unggulan dari usahatani dusungyang telah memberikan kontribusi bagi kehidupan masyarakat pedesaan dari generasi ke generasi. Komoditi usahatani dusung tersebut hampir seluruhnya dapat ditemui di dalam dusung di Kota Ambon dan memiliki produksi serta nilai jual yang tinggi, sehingga dapat memberikan masukan pendapatan yang memadai bagi petani.

Pada masyarakat kota Ambon, sistem dusung masih dapat dijumpai dan tetap dimanfaatkan pada beberapa desa baik yang terletak di daerah pegunungan dengan topografi berbukit sampai bergunung maupun pada daerah pesisir. Salah satunya adalah Desa 
Hutumuri. Sistem dusung sudah dikenal oleh masyarakat Desa Hutumuri sejak dahulu. Kenyataan yang terjadi di masyarakat bahwa seringkali terdapat kawasan hutan yang terpencar-pencar, namun usahatani dusung masih merupakan sumber mata pencaharian utama dan dilakukan untuk memperbaiki dan meningkatkan kesejahteraan petani yang hanya mempunyai lahan sempit melalui usaha peningkatan produksi dan peningkatan pendapatan serta mencegah kerusakan hutan. Pada daerah yang padat dengan lahan pertanian serba terbatas, sistem dusung sangat membantu di dalam pemecahan masalah kebutuhan hidup penduduk. Tingkat pendapatan dan kesejahteraan petani setempat terhadap pekerjaan pada usahatani dusung sebagai sumber mata pencaharian utama harus tetap dikembangkan, karena apakah dengan usahatani dusung dapat memperbaiki tingkat pendapatan dan petani yang berusahatani dusung dikategorikan sebagai penduduk sejahtera. Dengan demikian menarik untuk menganalisis pendapatan usahatani dusung di Desa Hutumuri Kota Ambon.

Bagi masyarakat, dusung mempunyai dua fungsi khusus yaitu : (1) Dapat menyediakan kebutuhan hidup petani berupa karbohidrat, protein dan mineral. (2) Dusung sebagai suatu ekosistem dapat menjamin kebutuhan hidup petani untuk meningkatkan kesejahteraan dan juga sebagai sumber utama mata pencaharian.

Desa Hutumuri merupakan salah satu desa di Kota Ambon Provinsi Maluku yang menerapkan pola dusung sebagai sistem bercocok tanam. Pola dusung sebagai bentuk pengelolaan lahan masih tetap dipertahankan sebagai sumber utama pendapatan keluarga, diwariskan oleh leluhur mereka dan masih dipraktekkan hingga kini sebagai upaya pemenuhan kebutuhan hidup dan peningkatan kesejahteraan keluarga. Banyak petani dusung yang mengelola usahataninya pada lahan kering dengan ditanami oleh berbagai jenis tanaman umur panjang dan tanaman semusim.

Komoditi-komoditi unggulan dari usahatani dusung di Desa Hutumuri, baik tanaman umur panjang seperti cengkeh, pala, durian, langsat, maupun umbi-umbian yang merupakan tanaman semusim seperti singkong dan keladi telah memberikan kontribusi bagi kehidupan masyarakat petani. Komoditi usahatani dusung yang sebahagian besar merupakan tanaman buah-buahan diharapkan dapat memenuhi kebutuhan kesejahteraan keluarga yang cenderung terus semakin meningkat. Oleh sebab itu dipandang merupakan suatu tuntutan kebutuhan adanya upaya terencana peningkatan produktivitas hasil usaha budidaya perkebunan pada lahan sempit, agar masih mampu memenuhi kebutuhan kesejahteraan keluarga. Sehingga diperlukan peningkatan faktor produksi yang mempengaruhi pendapatan petani dan pemasaran hasil produksi untuk meningkatkan pendapatan petani dari usahatani dusung.

Berdasarkan uraian diatas dapat dirumuskan beberapa permasalahan sebagai berikut :

1. Berapa besar biaya dan pendapatan yang diperoleh petani dari usahatani dusung di Desa Hutumuri.

2. Bagaimana kriteria kemiskinan dari petani yang mengusahakan usahatani dusung di Desa Hutumuri.

3. Apa sajakah faktor-faktor yang mempengaruhi pendapatan usahatani dusung di Desa Hutumuri.

Tujuan dari penelitian ini adalah untuk :

1. Mengetahui besarnya biaya dan pendapatan yang diperoleh petani dari usahatani dusung. 
2. Mengetahui kriteria kemiskinan petani yang mengusahakan usahatani dusung.

3. Mengetahui faktor-faktor yang mempengaruhi pendapatan usahatani dusung.

\section{METODE PENELITIAN}

\section{Metode Dasar}

Metode yang digunakan dalam penelitian ini adalah analisis deskriptif. Tujuannya memberikan gambaran secara sistematis, faktual dan akurat mengenai fakta-fakta, sifat-sifat serta hubungan antara fenomena yang diteliti, menguji hipotesis, membuat prediksi serta mendapatkan makna dan implikasi dari suatu masalah yang dipecahkan (Nasir, 1999). Pemecahan masalahnya dilakukan dengan mengumpulkan data, menyusun dan menganalisisnya. Hasilnya disajikan dalam bentuk deskripsi dan dilengkapi tabel-tabel.

\section{Penentuan Daerah Penelitian}

Daerah penelitian ditentukan secara sengaja (purposive) yaitu di Desa Hutumuri Kota Ambon berdasarkan pertimbangan tertentu. Desa Hutumuri dianggap sudah dapat mewakili keseluruhan desa atau kelurahan yang ada di Kota Ambon, dengan dasar pertimbangan bahwa desa tersebut sebahagian besar penduduknya bermata pencaharian sebagai petani, merupakan desa adat yang dekat dengan pusat kota dan masih menggunakan pola tanam dusung sebagai bentuk pengolahan lahan yang masih dipertahankan sebagai sumber utama pendapatan rumah tangga, diwariskan oleh leluruh mereka hingga kini sebagai upaya pemenuhan kebutuhan hidup dan peningkatan kesejahteraan keluarga.

\section{Penentuan Sampel}

Dalam penelitian ini diambil responden sebanyak 45 orang secara acak. Jumlah ini didasarkan pada prinsip keterwakilan dan pertimbangan homogenitas yang cukup besar pada Desa Hutumuri.

\section{Jenis dan Sumber Data}

Jenis data yang dikumpulkan adalah data primer dan data sekunder. Data primer adalah data yang langsung dikumpulkan dari petani sebagai responden, sesuai dengan daftar pertanyaan yang telah disiapkan. Sedangkan data sekunder meliputi datadata yang diperoleh dari instansi terkait, literature, catatan dan laporan yang ada kaitannya dengan penelitian. Teknik pengumpulan data yang digunakan adalah teknik wawancara, teknik pencatatan, dan teknik observasi.

\section{Pembatasan Masalah}

Adanya keragaman komoditi usahatani dusung, maka penulis membatasi jenis-jenis tanaman yang akan dianalisis dalam penelitian ini adalah jenis tanaman yang hampir seluruhnya dapat ditemui di dalam dusung di Desa Hutumuri dan memiliki produksi serta nilai jual yang tinggi, sehingga dapat memberikan masukan pendapatan yang memadai bagi petani. Jenis tanaman yang dimaksud adalah tanaman umur panjang seperti : cengkeh, pala, durian, langsat dan tanaman semusim yaitu umbi-umbian seperti singkong dan keladi.

Penelitian ini dilakukan untuk mengetahui jumlah pendapatan yang diterima petani dari usahatani dusung. Tanggal 25 Juli sampai dengan 25 Oktober 2016, merupakan jangka waktu yang digunakan peneliti dalam menganalisis pendapatan petani dari usahatani dusung di Desa Hutumuri.

\section{Metode Analisa}

Untuk menjawab tujuan penelitian dan membuktikan hipotesis digunakan metode analisis data. Beberapa analisis dalam penelitian ini 
adalah analisis pendapatan usahatani, serta persamaan fungsi Cobb-Douglas.

(1) Pendapatan usahatani dusung dapat dihitung dengan metode pendekatan pendapatan sebagai berikut :

$$
\begin{array}{ll}
\mathrm{NR} & =\mathrm{TR}-\mathrm{TC} \\
\mathrm{TR} & =\mathrm{Py} . \mathrm{Y} \\
\mathrm{TC} & =\mathrm{TVC}+\mathrm{TFC} \\
\mathrm{TVC} & =\mathrm{Px}_{1} \cdot \mathrm{x}_{1}+\mathrm{Px}_{2} \cdot \mathrm{x}_{2}+\ldots . . \\
+\mathrm{Px}_{3} \cdot \mathrm{x}_{3} &
\end{array}
$$

Keterangan :

$\mathrm{NR}=$ Pendapatan usahatani dusung

$$
\begin{aligned}
\mathrm{TR} & =\begin{array}{c}
\text { Total Revenue } \\
\text { (penerimaan total) }
\end{array} \\
\mathrm{TC} & =\text { Total Cost (biaya total) } \\
\mathrm{TVC} & =\begin{array}{c}
\text { Total Variabel Cost } \\
\text { (biaya variabel total) }
\end{array} \\
\mathrm{TFC} & =\begin{array}{l}
\text { Total Fixed Cost } \\
\text { (biaya tetap total) }
\end{array} \\
\mathrm{Px} & =\text { Harga per satuan input } \\
\mathrm{x}_{1}= & \text { Luas lahan } \\
\mathrm{x}_{2}= & \text { Penyusutan alat } \\
\mathrm{x}_{3}= & \text { Tenaga kerja } \\
\mathrm{P}_{\mathrm{y}}= & \text { Harga per satuan output } \\
\mathrm{Y} & =\text { Jumlah output }
\end{aligned}
$$

(2) Untuk mengetahui tujuan kedua peneliti menggunakan kriteria kemiskinan menurut Sayogyo (1983) untuk daerah pedesaan, yaitu dengan menggunakan tingkat pendapatan per kapita per tahun yang disetarakan ke dalam kilogram beras, dengan kriteria sebagai berikut :

a. Miskin sekali jika pendapatan per kapita per tahun $<240 \mathrm{~kg}$ beras.

b. Miskin jika pendapatan per kapita per tahun antara $240-$ $360 \mathrm{~kg}$ beras.

c. Nyaris Miskin jika pendapatan per kapita per tahun antara 360 $480 \mathrm{~kg}$ beras.

d. Tidak Miskin jika pendapatan per kapita per tahun > $480 \mathrm{~kg}$ beras.

\section{Pengujian Hipotesis Pertama :}

Hipotesis yang hendak di uji :

$\mathrm{H}_{0}: \mathrm{X} \leq 480 \mathrm{~kg}$ beras, artinya pendapatan petani dusung per tahun kurang dari $480 \mathrm{~kg}$ beras, sehingga petani di daerah penelitian dikategorikan miskin.

$\mathrm{H}_{\mathrm{a}}: \mathrm{X}>480 \mathrm{~kg}$ beras, artinya pendapatan petani dusung per tahun lebih dari $480 \mathrm{~kg}$ beras, sehingga petani di daerah penelitian dikategorikan tidak miskin.

Jika $X \leq 480 \mathrm{~kg}$ beras, maka terima $\mathrm{H}_{0}$ dan tolak $\mathrm{H}_{\mathrm{a}}$ jika $\mathrm{X}>480 \mathrm{~kg}$ beras, maka tolak $\mathrm{H}_{0}$ dan terima $\mathrm{H}_{\mathrm{a}}$.

(3) Faktor-faktor yang mempengaruhi tingkat pendapatan usahatani dusung, diketahui dengan menggunakan model persamaan fungsi Cobb-Douglas. Persamaan Cobb-Douglas dapat diformulasikan sebagai berikut : $\mathrm{Y}=\mathrm{f}\left(\mathrm{X}_{1}, \mathrm{X}_{2}, \mathrm{X}_{3}, \mathrm{X}_{4}, \mathrm{X}_{5}, \mathrm{X}_{6}, \mathrm{X}_{7}\right)$ $\mathrm{Y}=\mathrm{b}_{0} \mathrm{X}_{1}{ }^{\mathrm{b} 1} \mathrm{X}_{2}{ }^{\mathrm{b} 2} \mathrm{X}_{3}{ }^{\mathrm{b} 3} \mathrm{X}_{4}{ }^{\mathrm{b} 4} \mathrm{X}_{5}{ }^{\mathrm{b} 5} \mathrm{X}_{6}{ }^{\mathrm{b} 6}$ $\mathrm{X}_{7}^{\mathrm{b} 7} \mathrm{e}$

Untuk memudahkan pendugaan terhadap persamaan diatas maka persamaan tersebut diubah menjadi bentuk linear berganda dengan cara melogaritmakan persamaan tersebut, sebagai berikut :

$\ln \mathrm{Y}=\ln \mathrm{b}_{0}+\mathrm{b}_{1} \ln \mathrm{X}_{1}+\mathrm{b}_{2} \ln \mathrm{X}_{2}+$ $b_{3} \ln X_{3}+b_{4} \ln X_{4}+b_{5} \ln X_{5}+b_{6} \ln$ $\mathrm{X}_{6}+\mathrm{b}_{7} \mathrm{D}+\mathrm{e}$

$\begin{array}{ll}\text { Keterangan } & : \\ \mathrm{Y} & : \text { Pendapatan Usahatani } \\ & \text { dusung (Rp) } \\ & \text { : Intercept } \\ \mathrm{b}_{0} & \text { Koefisien regresi } \\ \mathrm{b}_{1}, \mathrm{~b}_{2}, \mathrm{~b}_{3}, \mathrm{~b}_{4}: & \text { Luas lahan (Are) } \\ \mathrm{x}_{1} & \text { : Umur (Tahun) } \\ \mathrm{x}_{2} & \text { : Penyusutan peralatan } \\ \mathrm{x}_{3} & \text { (Rp) } \\ & \text { : Jumlah tanggungan } \\ & \text { keluarga (Orang) }\end{array}$




$\begin{array}{ll}\mathrm{x}_{5} & : \begin{array}{l}\text { Pengalaman usahatani } \\ \text { dusung (Tahun) }\end{array} \\ & : \text { Pendidikan (Tahun) } \\ \mathrm{x}_{6} & : \text { Dummy } \\ \mathrm{D} & \text { (mengusahakan } \\ & \text { tanaman semusim }=1, \\ & \text { tidak mengusahakan } \\ & \text { tanaman semusim=0) } \\ & : \quad \text { Faktor pengganggu } \\ & \text { (error term) }\end{array}$

\section{Pengujian Hipotesis Kedua :}

\section{a. Koefisien Determinasi $\left(\mathbf{R}^{\mathbf{2}}\right)$}

Koefisien determinasi

mengindikasikan seberapa baiknya keseluruhan model regresi dalam menerangkan perubahan dalam nilai variabel dependen, (Samah dan Suandi, 1999). Secara matematis :

$\mathrm{R}^{2}=\frac{\mathrm{SSR}}{\mathrm{SST}}=\frac{\left[(\Sigma \mathrm{XY})^{2} / \mathrm{n} \Sigma \mathrm{X}^{2}-(\Sigma \mathrm{X})^{2}\right]}{\left[\Sigma \mathrm{Y}^{2}-(\Sigma \mathrm{Y})^{2} / \mathrm{n}\right]}$

SSR = Jumlah regresi kuadrat (Sum of Square for Regression)

SST = Jumlah kuadrat total (Total Sum of Square)

Koefisien determinasi yang rendah menunjukkan bahwa model tersebut tidak memadai untuk menjelaskan hal yang diteliti.

\section{b. Uji Signifikansi Simultan (Statistik F)}

Uji statistik F pada menunjukkan apakah semua variabel independen yang dimasukkan dalam model mempunyai pengaruh secara bersama-sama (simultan) terhadap variabel terikat, (Samah dan Suandi, 1999). Secara matematis :

$$
\mathrm{F}=\frac{\mathrm{MSR}}{\mathrm{MSE}}=\frac{\mathrm{SSR} / \mathrm{p}}{\mathrm{SSE} / \mathrm{n}-\mathrm{p}-1}
$$

Keterangan :

$\mathrm{n}=$ jumlah sampel

$\mathrm{p}=$ jumlah prediktor/variabel bebas

Hipotesis yang hendak diuji adalah :

- $\mathrm{H}_{0}: \beta_{1}=\beta_{2}=\beta_{\mathrm{k}}=0$; apakah luas lahan, umur, penyusutan peralatan, jumlah tanggungan keluarga, pengalaman usahatani dusung, pendidikan dan dummy, secara bersama-sama (simultan) bukan merupakan penjelas yang signifikan terhadap pendapatan usahatani dusung.

- $\mathrm{H}_{\mathrm{a}}: \beta_{1} \neq \beta_{2} \neq \beta_{\mathrm{k}} \neq 0$; apakah luas lahan, umur, penyusutan peralatan, jumlah tanggungan keluarga, pengalaman usahatani dusung, pendidikan dan dummy, secara bersama-sama (simultan) merupakan penjelas yang signifikan terhadap pendapatan usahatani dusung.

Jika nilai $F_{\text {hitung }}>F_{\text {tabel }}$ atau nilai signifikansinya lebih kecil daripada tingkat kesalahan yang ditetapkan $\left(\alpha_{0.1}\right)$, berarti hipotesis alternatif $\left(\mathrm{H}_{\mathrm{a}}\right)$ gagal ditolak, berarti bahwa ada ketergantungan antara variabel dependen dan sekelompok variabel independen dalam regresi itu.

\section{c. Uji Signifikasi Parameter Individual (Statistik t)}

Uji statistik $t$ menunjukkan seberapa besar pengaruh satu variabel independen secara individual dalam menerangkan variasi variabel dependen. Statistik t merupakan rasio antara nilai dari parameter estimasi dengan standar deviasinya. Secara matematis :

Keterangan :

$$
\mathrm{T}=\frac{\mathrm{Bi}}{\mathrm{S}_{\beta \mathrm{i}}}
$$

$\beta \mathrm{i} \quad=$ Parameter yang diestimasi

$\mathrm{S}_{\beta \mathrm{i}}=$ Standard error parameter yang diestimasi

Hipotesis yang hendak diuji adalah :

Ho : $\beta \mathrm{i}=0$ 
Artinya variabel independen tidak berpengaruh secara signifikan terhadap variabel dependen.

Ha : $\beta \mathbf{i} \neq 0$

Artinya variabel independen berpengaruh secara signifikan terhadap variabel dependen.

Jika nilai $F_{\text {hitung }}>\mathrm{F}_{\text {tabel }}$ berarti Ho ditolak, dan jika $F_{\text {hitung }}<F_{\text {tabel }}$ berarti Ho diterima.

\section{Uji Ekonometrika}

Uji ekonometrika digunakan untuk menguji apakah model yang digunakan telah memenuhi asumsi klasik untuk suatu model regresi linier, maka untuk menguji ketepatan model digunakan alat uji ekonometrika, yaitu :

\section{a. Uji Multikolinieritas}

Uji Multikolinieritas bertujuan untuk menguji apakah terdapat hubungan linier antara variabel independen di dalam regresi. Jika koefisien korelasi cukup tinggi (lebih dari 0,8) maka terjadi multikolinieritas dalam model. Langkah-langkah perbaikan multikolinieritas dapat dilakukan dengan mengeluarkan variabel-variabel yang bias, transformasi variabel dan penambahan data baru (Widarjono, 2005).

\section{b. Uji Heteroskedastisitas}

Uji Heterokedastisitas digunakan untuk mengetahui apakah dalam model regresi terjadi ketidaksamaan varians dari residual satu pengamatan ke pengamatan yang lain. Model regresi yang baik adalah yang tidak terjadi heterokedastisitas. Maka pengujian dilakukan dengan scatterplot, yaitu jika penyebaran residual teratur menunjukkan adanya heteroskedastisitas sedangkan jika penyebaran residual yang tidak teratur menunjukkan bebas heteroskedastisitas.

\section{c. Uji Normalitas}

Uji normalitas dilakukan untuk mengetahui apakah sebuah model regresi, variabel dependent, variabel independent atau keduanya mempunyai distribusi normal ataukah tidak. Model regresi yang baik adalah distribusi data normal atau mendekati normal. Untuk mendeteksi normalitas dilihat dengan grafik Normal P-P Plot yaitu dengan melihat penyebaran data (titik) pada sumbu diagonal dari grafik. Jika data menyebar di sekitar garis diagonal dan mengikuti arah garis diagonal, maka model regresi memenuhi asumsi Normalitas. Tetapi, jika data menyebar jauh dari garis diagonal dan/atau tidak mengikuti arah garis diagonal, maka model regresi tidak memenuhi asumsi Normalitas (Santoso, 2000).

\section{HASIL DAN PEMBAHASAN}

\section{Keadaan Usahatani Dusung}

Usahatani dusung telah lama dipraktekkan oleh petani di daerah penelitian, namun bagaimana sistem pemanfaatan lahannya, itu yang masih menjadi persoalan. Berbagai jenis tanaman yang ada di dalam dusung, sebagian besar telah mengalami perubahan dari tanaman yang dulunya adalah tanaman kelapa, kenari dan jenis-jenis tanaman hutan, sekarang ini lebih banyak didominasi oleh tanaman buah-buahan seperti durian dan langsat, tanaman perkebunan seperti cengkeh dan pala maupun tanaman pangan yaitu umbi-umbian seperti singkong dan keladi. Berdasarkan hasil pengamatan di lapangan, masyarakat memiliki dusung dengan luasan yang bervariasi mulai dari 100 Are hingga 700 Are. Namun dalam pengelolaannya masyarakat biasanya membagi penggunaannya sesuai dengan dekatnya pemukiman, biasanya yang paling dekat (50-500 meter) akan ditanami tanaman pangan dan tanaman buah-buahan maupun 
tanaman perkebunan yang membutuhkan penanganan intensif. Sedangkan yang agak jauh $(600-1.000$ meter) dari pemukiman ditanami tanaman tahunan dalam jumlah yang banyak, disamping tanaman buahbuahan atau tanaman hutan lainnya yang sudah ada di dalam dusung pada awal terbentuknya. Sedangkan dusung yang jauh dari pemukiman biasanya di dominasi oleh tanaman hutan, tanaman ini akan dipanen jika masyarakat betulbetul membutuhkan, misalnya untuk mendirikan rumah, kebutuhan anak sekolah dan sebagainya.

Lahan yang dimiliki pada umumnya pada satu tempat tetapi ada juga yang terpisah-pisah. Status kepemilikan lahan adalah milik sendiri, sehingga petani dengan bebas mengolah dan menerapkan teknologi serta teknik budidaya yang dikuasainya. Pengelolaan usahatani dusung oleh petani di daerah penelitian umumnya dilakukan secara tradisional dan tidak menggunakan teknologi atau alat-alat yang canggih mulai dari pembersihan lahan, pemeliharaan dan pemanenan. Karena bagi masyarakat pedesaan banyak sekali kendala atau hambatan dalam penggunaan alat yang canggih baik dari segi biaya, pemeliharaan dan lain-lain, sehingga mereka lebih cenderung menggunakan alat tradisional dalam proses pengolahan walaupun membutuhkan waktu yang cukup lama.

Dengan adanya sistem dusung ini maka masyarakat dapat menikmati hasil yang maksimal baik bagi si pemilik dusung itu sendiri, masyarakat yang kurang mampu dengan cara membantu dalam pengusahaan lahan maupun masyarakat lain yang membeli hasil panen dusung tersebut. Sistem dusung ini tidak melemahkan masyarakat atau kelompok lain yang tidak mempunyai dusung, sehingga rasa memiliki sangatlah tinggi dan akhirnya kesejahteraan hidup masyarakat pun terjamin.

Hasil yang diperoleh sebagian besar dijual ke pasar secara langsung oleh si pemilik dusung maupun melalui perantara atau biasa disebut "Papalele", dan sebahagian lagi digunakan bagi kebutuhan keluarga.

\section{Produksi Usahatani Dusung}

Produksi adalah suatu proses pendayagunaan sumber-sumber yang telah tersedia, dimana diharapkan terwujudnya hasil yang lebih dari segala pengorbanan yang telah diberikan (Hernanto, 1996). Dalam setiap proses produksi usahatani selalu menggunakan faktor-faktor produksi. Faktor produksi tersebut diatur dalam usahatani agar memperoleh produksi yang menguntungkan baik secara fisik maupun secara ekonomis.

Dari hasil penelitian, rata-rata produksi usahatani dusung yang tertinggi dihasilkan dari tanaman umur panjang yaitu dari komoditi langsat yaitu sebesar $816,67 \mathrm{~kg}$ dan produksi terendah terdapat pada tanaman semusim yaitu dari tanaman keladi sebesar 47,56 kg. 
Tabel 1. Rata-rata Produksi Usahatani Dusung di Desa Hutumuri , 2016.

\section{Usahatani Total Produksi (Kg) Rata-rata Produksi (Kg)}

a. Tanaman Umur Panjang

1. Cengkeh

153,31

2. Pala

- Biji

98,33

- Bunga

1.330

49,56

3. Durian

33.950

754,44

4. Langsat

36.750

816,67

b. Tanaman Semusim

1. Singkong

- Umbi

- Daun

2. Keladi

Sumber : Analisis Data Primer, 2016

Tabel 1. menunjukkan bahwa produksi yang dihasilkan petani di daerah penelitian cukup tinggi karena luas lahan yang ada dimanfaatkan secara optimal oleh petani. Berdasarkan pengamatan, produksi usahatani dusung diperoleh dari jenis komoditi yang berbeda-beda baik dari tanaman umur panjang maupun tanaman semusim.

Perbedaan produksi dari jenis komoditi yang diusahakan disebabkan oleh faktor alam, luas lahan, jumlah tanaman serta harga pasar yang menunjang. Faktor alam yang mempengaruhi produksi usahatani dusung di daerah penelitian adalah iklim dan cuaca serta musim panen. Berdasarkan hasil pengamatan yang dilakukan, tinggi rendahnya produksi disebabkan oleh iklim atau cuaca, dimana kalau musim cuaca hujan maka pohon yang sudah berbuah terlambat dipetik atau dipanen maka buah yang dihasilkan akan gugur dan busuk.

Faktor lain yang juga mempengaruhi produksi usahatani dusung yaitu jumlah tanaman atau banyaknya pohon yang ditanam. Semakin banyak jumlah pohon yang ditanam semakin banyak pula produksi yang dihasilkan. Luas lahan juga mempengaruhi produksi, apabila lahan luas serta diikuti dengan jumlah pohon yang ditanam maka semakin besar pula produksi yang dihasilkan. Jumlah produksi juga dipengaruhi oleh perlakuan pada masa panen. Jika banyaknya dahan atau batang pohon yang rusak maka produksi akan berkurang pada musim panen berikutnya.

\subsection{Biaya Produksi Usahatani Dusung}

Kegiatan produksi yang dilakukan memerlukan suatu korbanan. Korbanan yang dicurahkan dalam proses produksi ini, yang semula fisik kemudian diberikan nilai rupiah dan itulah yang kemudian diberi istilah biaya. Biaya ini tidak lain adalah nilai korbanan Hernanto, 1996). 
Tabel 2. Rata-rata Biaya Produksi Usahatani Dusung di Desa Hutumuri, 2016.

1. Penyusutan Peralatan

\section{Jenis Biaya}

2. Penyusutan Tanaman Umur Panjang

3. Tenaga Kerja

4. Pajak Lahan

5. Pemasaran
Jumlah Biaya (Rp)

39.656

3.750

2.706 .329

40.533

162.222

\section{Total}

2.952.490

Sumber : Analisis Data Primer, 2016

Perhitungan biaya keseluruhan dalam suatu produksi sampai pada produk itu siap dipasarkan atau didistribusikan adalah penting sekali guna mengetahui berapa besar pendapatan yang akan diterima dari usaha yang dijalankan. Hasil penelitian pada Tabel 2 menunjukkan bahwa ratarata biaya produksi usahatani dusung per tahun sebesar Rp. 2.952.490,-.
Biaya yang dikeluarkan oleh petani di daerah penelitian antara lain : biaya penyusutan peralatan, penyusutan tanaman umur panjang, tenaga kerja, pajak lahan dan biaya pemasaran.

Dengan perincian rata-rata biaya produksi usahatani dusung tahun 2016, sebagai berikut :

1. Biaya Penyusutan Peralatan

Tabel 3. Rata-rata Biaya Penyusutan Peralatan Menurut Jenis Peralatan yang digunakan dalam Usahatani Dusung di Desa Hutumuri, 2016.

\begin{tabular}{lcccc}
\hline $\begin{array}{c}\text { Jenis } \\
\text { Peralatan }\end{array}$ & $\begin{array}{c}\text { Jumlah } \\
\text { (Buah) }\end{array}$ & $\begin{array}{c}\text { Harga } \\
\text { Satuan (Rp) }\end{array}$ & $\begin{array}{c}\text { Jumlah Biaya } \\
\text { Peralatan (Rp) }\end{array}$ & $\begin{array}{c}\text { Jumlah Biaya } \\
\text { Penyusutan (Rp) }\end{array}$ \\
\hline Pacul & 0,95 & 40.000 & 38.000 & 6.080 \\
Linggis & 1,49 & 27.500 & 40.975 & 6.556 \\
Parang & 2,69 & 35.000 & 94.150 & 15.064 \\
Garuk & 0,62 & 55.000 & 34.100 & 5.456 \\
Hand-sprayer & 0,24 & 75.000 & 18.000 & 2.880 \\
Cangkul & 0,31 & 65.000 & 20.150 & 3.620 \\
\hline
\end{tabular}

Total

39.656

Sumber : Analisis Data Primer, 2016

Biaya penyusutan yang dimaksud adalah peralatan pertanian yang mendukung usahatani dusung. Peralatan yang digunakan dalam usahatani dusung berupa parang, cangkul, garuk, linggis, handsprayer, pacul dan bakul. Selain itu juga petani masih menggunakan peralatan-peralatan sederhana yang bahan-bahannya diambil dari alam, sehingga biaya yang dikeluarkan tidak terlalu besar. Harga satuan peralatan merupakan harga rata- rata peralatan pada saat petani melakukan proses pembelian.

\section{Biaya Penyusutan Tanaman Umur Panjang}

Biaya penyusutan tanaman umur panjang yang dimaksud adalah tanaman yang berumur lebih dari satu tahun yang memegang peranan penting dalam memberikan pendapatan bagi petani. Tanaman yang dimaksud adalah cengkeh, pala, durian, langsat. Dalam perhitungannya, biaya yang digunakan 
adalah biaya tenaga kerja. Petani dalam mengelola dusung hanya mengeluarkan biaya pemeliharaan dalam hal ini adalah biaya tenaga kerja. Sedangkan biayabiaya yang lain seperti pupuk, benih, pestisida, tidak dianggarkan, karena pengelolaan dusung masih dilakukan secara tradisional. Berdasarkan hasil penelitian rata-rata biaya penyusutan tanaman umur panjang yakni sebesar Rp. 3.750,-.

\section{Biaya Tenaga Kerja}

Biaya tenaga kerja merupakan upah yang diperoleh pekerja dalam melakukan usahatani. Untuk kegiatan usahatani petani mengunakan tenaga kerja dalam keluarga dan tenaga kerja luar keluarga. Tenaga kerja luar keluarga hanya digunakan pada kegiatan pemanenan. Sedangkan pada tahapan kegiatan yang lain petani menggunakan tenaga kerja dalam keluarga, hal ini disebabkan karena terbatasnya modal yang dimiliki oleh petani. Biaya tenaga kerja luar keluarga didasarkan tingkat upah yang berlaku di daerah penelitian. Sedangkan Tenaga kerja dalam keluarga berdasarkan Upah Minimum Regional Propinsi Maluku. Rata - Rata biaya tenaga kerja dapat dilihat pada tabel berikut.

Tabel 4. Rata-rata Biaya Penggunaan Tenaga Kerja dalam Usahatani Dusung di Desa Hutumuri, 2016.

\begin{tabular}{lrrrr}
\hline $\begin{array}{c}\text { Sumber Tenaga } \\
\text { Kerja }\end{array}$ & \multicolumn{1}{c}{ TKK } & $\Sigma$ Hari & $\begin{array}{c}\text { Upah Naker } \\
\text { Per Hari (Rp) }\end{array}$ & $\begin{array}{c}\text { Jumlah Biaya } \\
\text { TKDK (Rp) }\end{array}$ \\
\hline Dalam Keluarga & 2,31 & 150 & 2.917 & 1.010 .741 \\
Luar Keluarga & 2,38 & 28 & 25.444 & 1.695 .588 \\
\hline Sur
\end{tabular}

Sumber : Analisis Data Primer, 2016

Tenaga kerja usahatani merupakan faktor produksi selain tanah, modal dan pengelolaan. Dalam menjalankan usahatani dusung, tenaga kerja yang digunakan berasal dari dalam keluarga. Pada umumnya tenaga kerja yang digunakan sebanyak 3 (tiga) orang yaitu ayah, ibu dan anak. Tenaga kerja dalam keluarga biasanya digunakan untuk pemeliharaan dusung. Dimana jenis kegiatan yang dilakukan mulai dari pembersihan lahan sampai pemungutan hasil. Tetapi ada juga petani yang menggunakan tenaga kerja luar keluarga yang dikenal dengan istilah "Tenaga Kerja Sewa". Tenaga kerja sewa yang digunakan adalah tenaga kerja pria, yang biasanya dibutuhkan pada saat pemungutan hasil panen pada jenis-jenis tanaman yang jumlahnya banyak, sepeti tanaman cengkeh, pala, durian dan langsat.
Tenaga kerja sewa biasanya dibayar sekitar Rp.20.000,- sampai Rp.40.000,per harinya. Tetapi ada juga tenaga sewa yang dibayar dengan memperoleh sebahagian hasil panen. Hal ini dapat ditemui pada petani yang sudah sakitsakitan dan tidak dapat secara langsung mengelola dusung. Biasanya mereka akan dibutuhkan mulai dari pengolahan sampai pada pemanenan hasil. Semakin banyak tenaga sewa yang dipekerjakan maka semakin besar biaya yang harus dikeluarkan petani untuk membayar tenaga kerja.

\section{Biaya Pajak Lahan}

Petani di daerah penelitian menjalankan usahataninya bergerak atas tanah milik sendiri. Namun dikenai pajak dalam hal ini adalah pajak bumi, dengan luas lahan yang berbeda-beda. Rata-rata biaya pajak lahan yang harus 
dikeluarkan oleh petani di daerah penelitian adalah sebesar Rp. 40.533,-. Dengan demikian, semakin besar luas lahan maka semakin besar pula biaya yang harus dikeluarkan.

\section{Biaya Pemasaran}

Biaya pemasaran ini meliputi biaya transportasi pulang pergi dan biaya makan. Rata-rata biaya pemasaran yang harus dikeluarkan oleh petani di daerah penelitian adalah sebesar Rp. 162.222,-. Kecilnya biaya pemasaran karena sebahagian besar petani melakukan pemanenan hasil satu atau dua kali dalam satu tahun sehingga untuk memasarkannya memerlukan biaya yang tidak terlalu besar, serta ditunjang oleh letak pusat pemasaran yang tidak terlalu jauh dari daerah penelitian disamping adanya pedagang pengecer lokal yang langsung membeli hasil panen tersebut.

\section{Penerimaan Usahatani Dusung}

Berdasarkan hasil penelitian diperoleh rata-rata penerimaan usahatani dusung sebesar Rp. 26.394.305,- dengan tingkat penerimaan tertinggi diperoleh dari tanaman umur panjang yaitu dari tanaman pala yaitu sebesar Rp. 8.681.480,- dan terendah diperoleh dari tanaman semusim yaitu dari tanaman singkong sebesar Rp. 1.702.140,-.

Tabel 5. Rata-rata Penerimaan Petani Per Tahun Menurut Jenis Komoditi yang diusahakan di dalam Dusung di Desa Hutumuri, 2016.

\begin{tabular}{|c|c|c|c|}
\hline Usahatani & $\begin{array}{c}\text { Produksi (Kg/1 } \\
\text { orang petani) }\end{array}$ & $\begin{array}{c}\text { Harga Jual } \\
\text { (Rp/Kg) }\end{array}$ & $\begin{array}{c}\text { Penerimaan }(\mathrm{Rp} / 1 \\
\text { orang petani) }\end{array}$ \\
\hline \multicolumn{4}{|c|}{ a. Tanaman Umur Panjang } \\
\hline 1. Cengkeh & 153,31 & 51.000 & 7.818 .810 \\
\hline \multicolumn{4}{|l|}{ 2. Pala } \\
\hline - Biji & 98,33 & 52.000 & 5.113 .160 \\
\hline - Bunga & 49,56 & 72.000 & 3.568 .320 \\
\hline 3. Durian & 754,44 & 5.000 & 3.772 .200 \\
\hline \multirow[t]{2}{*}{ 4. Langsat } & 816,67 & $2 . .500$ & 2.041675 \\
\hline & & & 22.314.165 \\
\hline \multicolumn{4}{|c|}{ a. Tanaman Semusim } \\
\hline \multicolumn{4}{|c|}{ 1. Singkong } \\
\hline - Umbi & 66,89 & 25.000 & 1.672 .250 \\
\hline - Daun & 29,89 & 1.000 & 29.890 \\
\hline \multirow[t]{3}{*}{ 2. Keladi } & 47,56 & 50.000 & 2.378 .000 \\
\hline & & & 4.080 .140 \\
\hline & Total & & 26.394.305 \\
\hline
\end{tabular}

Sumber : Analisis Data Primer, 2016

Penerimaan adalah jumlah produksi dikali dengan harga jual. Ratarata penerimaan usahatani dusung sebesar Rp. 26.394.305,- per tahun. Jumlah ini merupakan nilai produk total usahatani dusung dalam jangka waktu satu tahun, yang dijual untuk menambah pendapatan dan memenuhi kebutuhan hidup sehari-hari.

Penerimaan yang sebesarbesarnya adalah sasaran akhir bagi petani, sebab dengan peningkatan penerimaan tersebut berbagai tujuan (individu, keluarga) akan dapat tercapai. Perbedaan tingkat penerimaan yang 
diperoleh petani dusung di daerah penelitian disebabkan oleh besar kecilnya usaha, banyak sedikitnya produksi yang dihasilkan serta keadaan pasar yang menunjang pada saat hasil produksi dijual. Hal ini dapat dilihat pada komoditi cengkeh dan pala yang jumlah produksinya per tahun di daerah penelitian tergolong rendah tetapi mendatangkan penerimaan yang besar bagi petani disebabkan harga pasar yang sangat menunjang. Sementara untuk komoditi langsat yang jumlah produksinya tertinggi setiap tahunnya tetapi mendatangkan penerimaan yang kecil disebabkan karena harga jual yang rendah. Untuk komoditi durian, sudah memenuhi kedua aspek diatas, dimana produksinya banyak serta ditunjang dengan harga pasar yang memadai maka penerimaan yang diperoleh petani juga akan memuaskan. Sedangkan untuk tanaman semusim, merupakan pemasok penerimaan yang terendah setiap tahunnya disebabkan karena kurangnya petani yang mengusahakannya sehingga produksi yang dihasilkan sedikit, walaupun harga pasar menunjang.

\section{Pendapatan Usahatani Dusung}

Hasil penelitian menunjukkan bahwa pendapatan petani dusung diperoleh dari beberapa jenis tanaman, baik tanaman umur panjang seperti cengkeh, pala, durian dan langsat maupun tanaman semusim seperti singkong dan keladi

Tabel 6. Rata-rata Penerimaan, Biaya Produksi dan Pendapatan Petani Per Usahatani/per Tahun Pada Usahatani Dusung di Desa Hutumuri, 2016.

\begin{tabular}{cccc}
\hline \multicolumn{2}{c}{ Penerimaan } & $\begin{array}{c}\text { Biaya } \\
\text { Produksi (Rp) }\end{array}$ & $\begin{array}{c}\text { Pendapatan } \\
(\text { Rp) }\end{array}$ \\
\cline { 1 - 2 } Tanaman Umur Panjang & Tanaman Semusim & 2.952 .490 & $\mathbf{1 8 . 1 0 3 . 3 6 1}$ \\
\hline
\end{tabular}

Sumber : Analisis Data Primer, 2016

Keberhasilan dari usahatani akhirnya akan dinilai pada besarnya pendapatan bersih yang merupakan sasaran akhir dari petani. Pendapatan usahatani dusung merupakan selisih antara penerimaan usahatani dusung dengan seluruh biaya yang dikeluarkan untuk proses produksi.

Hasil penelitian yang ditunjukkan pada Tabel 6, rata-rata penerimaan tertinggi diperoleh dari tanaman umur panjang sebesar Rp. 22.314.165,- dan penerimaan terendah dari tanaman semusim sebesar Rp. 4.080.140,-, dengan rata-rata biaya produksi Rp. 2.952.490,-, sehingga rata-rata pendapatan yang diperoleh dari usahatani dusung adalah sebesar Rp. 23.441.815,- per tahun atau Rp.
1.953.485,- per bulan. Pendapatan yang diperoleh petani responden di daerah penelitian cukup tinggi karena berdasarkan Lampiran Keputusan Gubernur Maluku tentang penetapan atas Upah Minimum Provinsi Maluku (UMP) Tahun 2016 sebesar Rp. 1.775.000,- per bulan atau Rp. 21.300.000,- per tahun, maka usahatani dusung masih memberikan pendapatan yang tinggi bagi petani. Tingginya pendapatan yang diperoleh dipengaruhi oleh luas lahan, jenis komoditi yang ditanam yang bernilai ekonomis tinggi, pemeliharaan yang cukup baik serta yang paling menentukan adalah faktor alam, dalam hal ini musim panen. Berdasarkan pengamatan dan wawancara dengan petani di daerah penelitian, skala usaha dalam jumlah 
yang besar akan menghasilkan produksi yang besar serta pendapatan yang besar begitupun sebaliknya. Pendapatan yang besar juga didukung oleh harga pasar yang menunjang.

Tingkat pendapatan petani juga dipengaruhi oleh skala usaha. Besarnya pendapatan petani dipengaruhi oleh skala usaha yang besar, dimana efisiensi skala produksi bagi petani agar penanganan sumber-sumber ekonomi seperti luas lahan dan curahan tenaga kerja yang dimiliki oleh petani dapat diatur seefisien mungkin. Efisiensi produksi yaitu banyaknya hasil produksi (output) yang dapat diperoleh dari satu faktor produksi (input).

Besarnya pendapatan petani juga dipengaruhi oleh kemampuan petani dalam memanfaatkan peluang pasar. Peluang pasar yang dimaksudkan adalah peluang petani untuk menjual atau memasarkan hasil pertanian sehingga mendapatkan keuntungan yang memadai. Petani harus aktif dalam mengetahui informasi pasar sehingga petani tidak berada pada posisi yang lemah dan hal tersebut tidak membuat petani dirugikan. Dalam hal ini petani dalam menjalankan usahatani dusung harus memperhatikan permintaan pasar. Disamping adanya pemasokan jenis produk yang sama dari luar daerah, menyebabkan petani akan bersaing dalam menjual hasil panennya. Oleh sebab itu petani harus memiliki kemampuan dalam menganalisis kondisi yang dialami serta berusaha untuk menemukan jalan keluar yang terbaik untuk pemasaran hasil panennya.

Tingkat pendapatan petani juga dipengaruhi oleh fluktuasi harga pasar. Dimana naik turunnya harga di pasar sangat mempengaruhi pendapatan petani. Dengan demikian pendapatan yang diperoleh akan meningkat sesuai peningkatan penerimaan, dengan asumsi bahwa hasil tersebut laku dipasaran dengan tingkat harga konstan seperti yang diinginkan petani. Dimana pendapatan yang diterima petani besar karena harga jualnya tinggi serta adanya pedagang pengumpul tetap seperti agenagen penjualan, khususnya pada tanaman cengkeh dan pala.

\section{Kriteria Kemiskinan Petani Dusung} Tingkat kesejahteraan rumahtangga diukur dari besarnya pendapatan rumahtangga pengrajin dengan menggunakan kriteria Sayogyo (1983) untuk daerah pedesaan, yaitu dengan menggunakan tingkat pendapatan per kapita per tahun yang disetarakan ke dalam kilogram beras, dengan kriteria sebagai berikut :

a. Miskin sekali jika pendapatan per kapita per tahun $<240 \mathrm{~kg}$ beras.

b. Miskin jika pendapatan per kapita per tahun antara $240-360 \mathrm{~kg}$ beras.

c. Nyaris Miskin jika pendapatan per kapita per tahun antara $360-480 \mathrm{~kg}$ beras.

d. Tidak Miskin jika pendapatan per kapita per tahun $>480 \mathrm{~kg}$ beras.

Suatu rumahtangga di pedesaan dikatakan tidak miskin jika pendapatan perkapita per tahun setara dengan nilai tukar beras di atas $480 \mathrm{~kg}$. dari kriteria tersebut maka dapat ditentukan tingkat kesejahteraan rumahtangga petani dusung di daerah penelitian dengan standar harga beras saat penelitian tahun 2016 adalah Rp. 10.000,-/kg. Jumlah anggota rumahtangga yaitu 4 (empat) orang. 
Tabel 7. Distribusi Petani Dusung Menurut Pendapatan Per Kapita Per Tahun di Desa Hutumuri, 2016.

\begin{tabular}{|c|c|c|c|c|}
\hline No. & $\begin{array}{c}\text { Golongan Pendapatan } \\
\text { (Rp/Kapita/Tahun) }\end{array}$ & $\begin{array}{c}\text { Kriteria } \\
\text { Kemiskinan }\end{array}$ & $\begin{array}{l}\text { Jumlah } \\
\text { (Orang) }\end{array}$ & $\begin{array}{l}\text { Persentase } \\
(\%)\end{array}$ \\
\hline 1 & $\begin{array}{l}<1.440 .000 \\
(\text { setara }<240 \mathrm{~kg} \text { beras })\end{array}$ & Miskin Sekali & 0 & 0 \\
\hline 2 & $\begin{array}{l}1.440 .000-2.160 .000 \\
\text { (setara } 240-360 \mathrm{~kg} \text { beras) }\end{array}$ & Miskin & 0 & 0 \\
\hline 3 & $\begin{array}{l}2.160 .000-2.880 .000 \\
\text { (setara } 360-480 \mathrm{~kg} \text { beras) }\end{array}$ & Nyaris Miskin & 0 & 0 \\
\hline 4 & $\begin{array}{l}>2.880 .000 \\
(\text { setara }>480 \mathrm{~kg} \text { beras })\end{array}$ & Tidak Miskin & 45 & 100 \\
\hline \multicolumn{3}{|c|}{ Jumlah } & 45 & 100 \\
\hline $\mathbf{R a}$ & 1-rata Pendapatan Petani & sung Per Tahun & \multicolumn{2}{|c|}{ Rp. 23.441.815 } \\
\hline
\end{tabular}

Sumber : Analisis Data Primer, 2016.

Tabel 7 menunjukkan bahwa, usahatani dusung merupakan usaha yang sangat membantu perekonomian keluarga petani dalam pemenuhan seluruh kebutuhan rumahtangga. Berdasarkan hasil penelitian golongan Pendapatan (Rp/Kapita/Tahun) Tertinggi : Rp. 46.133.476,-. Sedangkan golongan (Rp/Kapita/Tahun) Terendah : Rp.4.276.336,-.

Kesejahteraan dalam penelitian ini adalah kesejahteraan ekonomi yang diukur dari pendapatan rumahtangga petani dusung yang diperoleh dari usahatani dusung. Berdasarkan hasil analisis, rata-rata pendapatan per kapita per tahun petani dusung adalah Rp. 23.441.815,-. Jika pendapatan ini disetarakan dengan beras (harga beras pada saat penelitian Rp. $10.000,-/ \mathrm{kg}$ ) maka pendapatan per kapita per tahun petani dusung setara dengan lebih besar dari $480 \mathrm{~kg}$ beras yaitu 4.069,7 kg beras. Menurut Sayogyo jika seseorang memiliki pendapatan per kapita per tahun yang disetarakan dengan beras di atas $480 \mathrm{~kg}$ beras berarti petani dusung dikategorikan tidak miskin. Pendapatan petani dusung per tahun adalah $\mathrm{Rp}$. 23.441.815,-. Ini menunjukkan bahwa petani dusung sejahtera.

Pendapatan usahatani dusung berada di atas tolak ukur garis kemiskinan atau lebih besar dari kriteria Sayogyo (1983). Pendapatan dari usahatani dusung memberikan peranan penting dalam peningkatan kesejahteraan rumahtangga petani di daerah penelitian.

\section{Faktor-faktor yang Mempengaruhi Pendapatan Usahatani Dusung}

Pendapatan yang diterima oleh petani dari usahatani dusung di Desa Hutumuri dipengaruhi oleh Luas Lahan, Umur, Penyusutan Peralatan, Jumlah Tanggungan Keluarga, Pengalaman Usahatani, Pendidikan dan Dummy. 
Tabel 8. Hasil Analisis Regresi Pendapatan Usahatani Dusung di Desa Hutumuri, 2016.

\begin{tabular}{clrrrr}
\hline No. & \multicolumn{1}{c}{ Variabel } & $\begin{array}{c}\text { Coeffi } \\
\text { Cients }\end{array}$ & $\begin{array}{c}\text { Std. } \\
\text { Error }\end{array}$ & t-Statistic & \multicolumn{1}{c}{ Prob } \\
\hline 1 & C & $12,462^{* * *}$ & 0,537 & 23,202 & 0,000 \\
2 & Luas Lahan & $0,213^{* * *}$ & 0,020 & 10,607 & 0,000 \\
3 & Umur & $-0,033^{* *}$ & 0,013 & $-2,599$ & 0,013 \\
4 & Penyusutan Peralatan & $0,758^{* * *}$ & 0,137 & 5,537 & 0,000 \\
5 & Jumlah Tanggungan & $-0,086^{* * *}$ & 0,014 & $-6,226$ & 0,000 \\
& Keluarga & & & & \\
6 & Pengalaman Usahatani & $-0,220^{* * *}$ & 0,020 & $-7,081$ & 0,000 \\
7 & Pendidikan & $0,307^{* * *}$ & 0,032 & 9.669 & 0,000 \\
8 & Dummy & $0,583^{* * *}$ & 0,052 & 11.322 & 0,000 \\
9 & R-squared & & & & 0,934 \\
10 & Adjusted R-squared & & & & 0,921 \\
11 & Std. Error of the & & & & 0,154 \\
& Estimate & & & & 1,893 \\
12 & Durbin-Watson & & & & $0,000 * * *$ \\
13 & F-statistic & & & & \\
14 & Prob (F-statistic) & & & & \\
\hline
\end{tabular}

Sumber : Analisis Data Primer (diolah dengan SPSS), 2016.

Keterangan :

D : Dummy tanaman semusim

*** : Signifikan pada tingkat kepercayaan 1

** : Signifikan pada tingkat kepercayaan 5\%

* : Signifikan pada tingkat kepercayaan $10 \%$

Tabel 8 menunjukkan bahwa nilai F hitung sebesar 74,252 lebih besar dari nilai $\mathrm{F}$ tabel pada tingkat kepercayaan 1\%. Hal ini berarti bahwa pendapatan usahatani dusung dipengaruhi secara bersama-sama oleh variabel independen.

Besarnya keragaman variabel dependen (pendapatan usahatani dusung) yang dapat dijelaskan oleh variabel independen ditunjukkan oleh besarnya nilai koefisien determinasi $\left(\mathrm{R}^{2}\right)$. Nilai sebesar 0,934 yang berarti bahwa 93,4\% keragaman variabel dependen yang dimasukkan dalam model dapat menjelaskan keragaman variabel independen. Sedangkan 6,6\% diterangkan oleh variabel lain diluar model.

Untuk mengetahui variabel independen yang nyata pengaruhnya terhadap pendapatan usahatani dusung digunakan uji t. Hasil analisis dengan menggunakan uji $t$ dua arah menunjukkan bahwa luas lahan, penyusutan peralatan, jumlah tanggungan keluarga, pengalaman usahatani, pendidikan dan dummy berpengaruh nyata terhadap pendapatan usahatani dusung pada tingkat kepercayaan 1\%, sedangkan umur berpengaruh nyata terhadap pendapatan usahatani dusung pada tingkat kepercayaan $5 \%$.

$\begin{array}{ccr}\text { Hasil } & \text { analisis } & \text { regresi } \\ \text { menunjukkan } & \text { bahwa } & \text { luas } \\ \text { berpengaruh } & \text { positif } & \text { terhanan }\end{array}$ pendapatan usahatani dusung atau setiap penambahan lahan yang dapat diberdayakan untuk kegiatan usahatani sebesar $1 \%$ akibatnya akan menambah pendapatan petani dari usahatani 
dusung sebesar 0,213\%. Jika luas areal dusung naik, maka tingkat produksi juga akan meningkat. Pada tingkat harga yang sama pendapatan usahatani juga akan meningkat.

Umur berpengaruh negatif terhadap pendapatan usahatani dusung atau setiap penambahan umur sebesar $1 \%$ maka pendapatan petani dari usahatani dusung akan turun sebesar $0,033 \%$. Pertambahan umur seorang petani, membuat petani semakin tua dan sakit-sakitan sehingga tidak dapat mengelola dusung secara optimal. Dengan demikian petani harus menyewa tenaga kerja untuk mengelola hasil-hasil dusung sehingga biaya yang dikeluarkan bertambah, yang berakibat pada turunnya pendapatan yang akang diperoleh petani.

Penyusutan peralatan berpengaruh positif terhadap pendapatan atau setiap penambahan $1 \%$ biaya penyusutan peralatan maka pendapatan usahatani dusung akan naik sebesar 0,758\%. Semakin banyak peralatan yang digunakan membuat petani semakin giat dalam mengelola usahatani dusung yang akan berdampak pada peningkatan hasil produksi sehingga pendapatan yang diperoleh akan bertambah.

Jumlah tanggungan keluarga berpengaruh negatif terhadap pendapatan atau setiap penambahan $1 \%$ tanggungan keluarga maka pendapatan usahatani dusung akan turun sebesar $0,086 \%$. Semakin banyak tanggungan keluarga menyebabkan petani harus bekerja di luar usahatani dusung untuk memenuhi kebutuhan keluarga. Hal ini menyebabkan berkurangnya alokasi waktu kerja petani di areal dusung sehingga ada beberapa kegiatan pada usahatani dusung yang ditinggalkan, mengakibatkan hasil produksi akan mengalami penurunan yang berakibat pada turunnya pendapatan petani.
Pengalaman berusahatani dusung berpengaruh negatif terhadap pendapatan atau apabila pengalaman dalam berusahatani dusung mengalami penambahan $1 \%$ maka pendapatan akan mengalami penurunan sebesar $0,144 \%$. Tanda negatif berarti perubahan pendapatan petani dari usahatani dusung tidak searah dengan pengalamannya dalam berusahatani. Dapat dijelaskan bahwa bertambahnya pengalaman dalam berusahatani dusung tetapi jika petani tidak berada pada usia produktif untuk bekerja menyebabkan petani tidak dapat mengerahkan semua kemampuannya untuk berusahatani dusung dengan baik, sehingga hasil produksi yang diperoleh mengalami penurunan yang berakibat pada turunnya pendapatan. Selain itu, tingkat pendidikan yang rendah serta tidak adanya modal yang mendukung dalam pengelolaan usahatani membuat petani tidak dapat mengembangkan usahatani untuk meningkatkan hasil produksi, walaupun adanya pertambahan pengalaman dalam berusahatani, sehingga pendapatan yang diperoleh petani mengalami penurunan.

Pendidikan berpengaruh positif terhadap pendapatan atau setiap penambahan tingkat pendidikan sebesar $1 \%$ maka pendapatan usahatani dusung akan naik sebesar 0,307\%. Tingkat pendidikan yang tinggi memberikan dampak positif bagi petani. Dimana petani memiliki kemampuan yang lebih dalam mengelola usahatani dusung. Pengelolaan akan dilakukan secara optimal, dengan menerapkan teknikteknik berusahatani yang baik yang akan berakibat pada peningkatan hasil produksi sehingga pendapatan yang diperoleh akan bertambah apabila ditunjang juga oleh harga jual yang tinggi. 
Variabel dummy mempunyai nilai koefisien regresi sebesar 0,583 dan menunjukkan perbedaan yang nyata pada tingkat kepercayaan $1 \%$. Hal ini berarti mengusahakan tanaman semusim di areal dusung berpengaruh positif terhadap pendapatan. Petani yang mengusahakan tanaman semusim dapat meningkatkan pendapatannya karena selain memperoleh pendapatan dari tanaman umur panjang, tanaman semusim juga dapat memberikan pemasukan yang besar bagi petani jika didukung oleh luas lahan serta jumlah produksi yang memadai.

\section{Uji Ekonometrika}

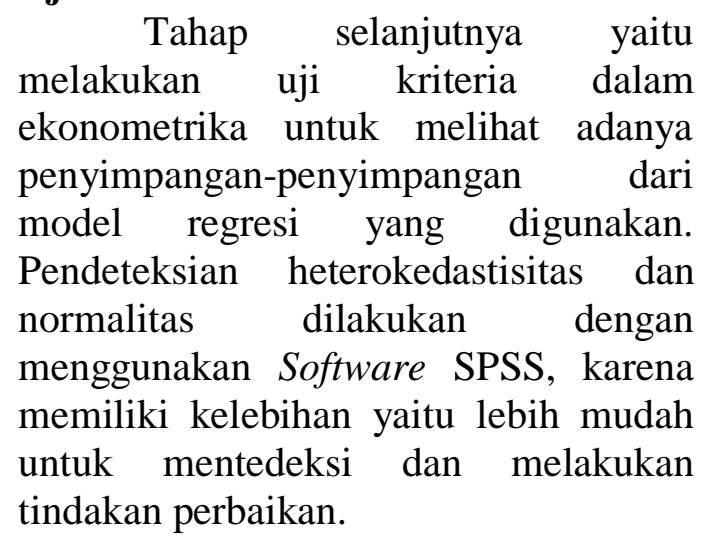

\section{a. Uji Heteroskedastisitas}

Pada uji heteroskedastisitas analisis regresi faktor-faktor yang mempengaruhi pendapatan usahatani dusung tidak ditemukan adanya heteroskedastisitas, terbukti dari sebaran residual yang tidak teratur dan tidak membentuk sebuah pola tertentu yang jelas serta tersebar baik di atas maupun di bawah angka 0 pada sumbu Y.

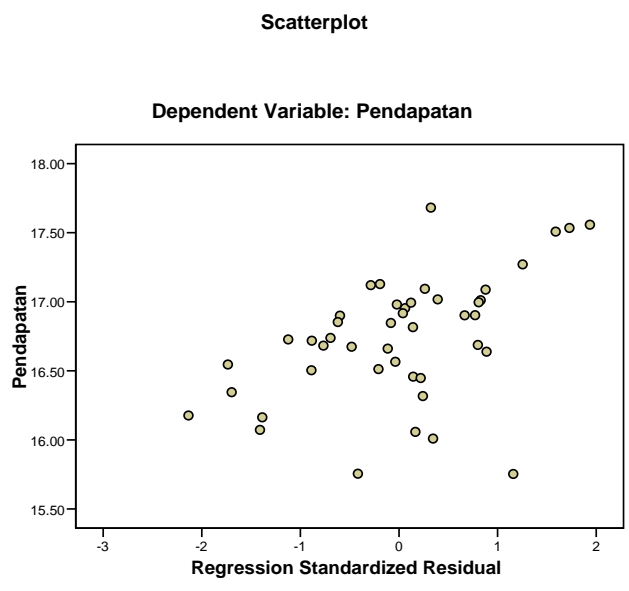

\section{b. Uji Normalitas}

Pada uji normalitas analisis regresi faktor-faktor yang mempengaruhi pendapatan usahatani dusung dapat dilihat bahwa titik-titik menyebar di sekitar garis diagonal, serta penyebarannya mengikuti garis diagonal. Maka model regresi layak dipakai untuk memprediksi pendapatan berdasarkan masukan variabel independentnya.

Normal P-P Plot of Regression Standardized Residual

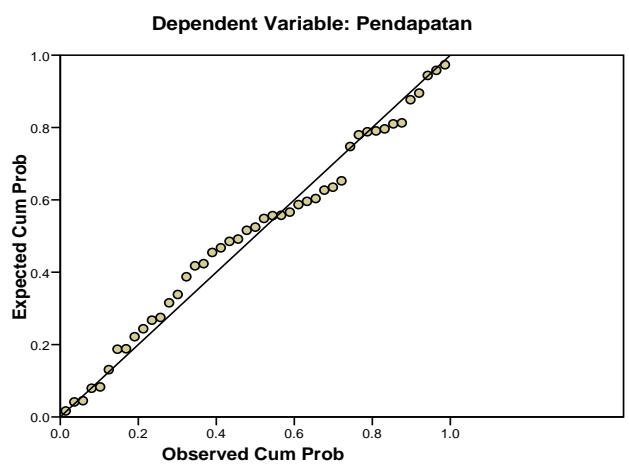

KESIMPULAN

Berdasarkan analisis hasil penelitian dan pembahasan dapat disimpulkan beberapa hal, antara lain :

1. Usahatani dusung di Desa Hutumuri masih produktif sebagai sumber pendapatan rumahtangga karena memberikan kontribusi lebih besar 
bagi petani dibandingkan dengan UMP yang ditetapkan Pemerintah Provinsi Maluku. Rata-rata pendapatan yang diperoleh petani responden di daerah penelitian per tahun sebesar Rp. 23.441.815,-, sehingga usahatani dusung tetap layak untuk dikembangkan.

2. Pendapatan petani per tahun yang disetarakan dengan beras di atas 480 $\mathrm{kg}$ beras berarti petani dusung dikategorikan tidak miskin. Pendapatan petani dusung per tahun adalah Rp. 23.441.815,-. Ini menunjukkan bahwa petani dusung sejahtera. Dimana pendapatan petani dari usahatani dusung berada di atas tolak ukur garis kemiskinan atau lebih besar dari kriteria Sayogyo (1983). Pendapatan usahatani dusung memberikan peranan penting dalam peningkatan kesejahteraan rumahtangga petani di daerah penelitian.

3. Pendapatan petani dari usahatani dusung dapat ditingkatkan apabila dikaitkan dengan ketersediaan lahan. Peningkatan luas lahan untuk berusahatani dusung serta menambah jenis tanaman yang diusahakan di areal dusung, khususnya penanaman tanaman semusim dapat meningkatkan pendapatan petani yang bersumber dari usahatani dusung.

\section{DAFTAR PUSTAKA}

Ayawaila, J. W. 1996. Tinjauan Sosial Budaya Agroforestry Dusung. Pusat Studi Maluku. Universitas Pattimura, Ambon.

Badrun, Muhammad. 2000. Penerapan

$\begin{array}{lrr}\text { Paket Teknologi } & \text { Usaha } \\ \text { Budidaya } & \text { Lahan } & \text { Kering } \\ \text { Berkelanjutan } & \text { Mendukung } \\ \text { Kebijaksanaan } & \text { Ketahanan }\end{array}$

Pangan : Suatu Catatan

Pengalaman pada

Pengembangan Perkebunan.

Makalah disampaikan pada

Diskusi Panel MMA-IPB,

Tanggal 2 Mei 2000. Bogor.

Hernanto, F. 1996. Ilmu Usahatani. Penebar Swadaya, IKAPI Jakarta.

Muniarti dan Siregar. U. J. 1996. Usahatani Agroforestry Menuju Lingkungan. Makalah disampaikan pada Lokakarya Peranan Dusung terhadap Kelestarian Lingkungan. Kerja sama WIPTEK-CIDA. Universitas Ambon.

Mubyarto. 1989. Pengantar Ekonomi Pertanian. Lembaga Penelitian Pendidikan dan Pengajaran Ekonomi dan Sosial, Jakarta.

Oszaer. 1996. Sistem Agroforestry. Makalah disampaikan dalam Lokakarya Wanita Dalam Sains dan Teknologi Universitas Pattimura Ambon.

Soekartawi, 2003, Teori Ekonomi Produksi dengan Pokok Bahasan Analisis Fungsi CobbDouglas, PT. Raja Grafindo Persada, Jakarta.

Suratiyah, K. 2006. Ilmu Usahatani. Penebar Swadaya. Jakarta.

Santoso, S. 2000. Buku Latihan SPSS Statistik Parametrik. PT. Elex Media Komputindo Kelompok Gramedia. Jakarta.

Sayogyo, 1983. Menelaah Garis Kemiskinan. Makalah pada Lokakarya Metodologi. KajiTindak Proyek Pembinaan Petani Kecil. Cisarua. Bogor.

Widarjono, A. 2005. Ekonometrika : Teori dan Aplikasi untuk Ekonomi dan Bisnis. Penerbit Ekonisia Fakultas Ekonomi UII. Yogyakarta. 